\title{
Implications of Cocoa Pod Storage and Temperature to the Performance of Pod Components and Seedling Growth
}

\author{
Ari Wibowo*1), Indah Anita-Sari ${ }^{1)}$, and Agung Wahyu Susilo ${ }^{1)}$ \\ ${ }^{1}$ Indonesian Coffee and Cocoa Research Institute, Jl. PB Sudirman No. 90, Jember, Indonesia \\ ${ }^{*}$ Corresponding author: ariwibowo.iccri@gmail.com \\ Received: 10 February 2021 / Accepted: 07 March 2021
}

\begin{abstract}
Cocoa seeds are recalcitrant with some problems in their storage due to lack of dormancy period. This study aimed to find out the effect of cocoa pod storage in two different temperatures and the storage period towards seed viability and growth of the seedlings. This study applied a split-plot design with storage temperature as main plot and storage period as sub-plot. Cocoa pods of Sulawesi-1 clone were harvested and stored at $20^{\circ} \mathrm{C}$ and $29^{\circ} \mathrm{C}$ for $3,7,14$, and 30 days. The stored cocoa seeds were then sown for three months. The findings showed that the storage of cocoa pods at $20^{\circ} \mathrm{C}$ for 30 days causing the seed water content was $45 \%$, the growth of the seedlings after the storage was $98.7 \%$, and could press the pod shrinkage $(1.6 \%)$. The storage of cocoa pods at $29^{\circ} \mathrm{C}$ for 30 days could accelerate the reduction process by $68.2 \%$, decreased germination of seeds up to $83.4 \%$, and reduced the water content by $44.2 \%$. The pod storage at $20^{\circ} \mathrm{C}$ for 30 days showed a high value in some aspects such as seedling height, stem diameter, leaf area, seedling fresh weight, and shoot/root ratio. The storage of pods at $29^{\circ} \mathrm{C}$ for 14 days indicated a high score in the character of germination, seedling height, stem diameter, and fresh weight of seedlings. The storage of pods at room temperature could be conducted for 14 days, meanwhile, at controlled temperature, it could be conducted for 30 days.
\end{abstract}

Keyword: cocoa, pod storage, seedling quality, temperature

\section{INTRODUCTION}

Cocoa seeds are recalcitrant that normally require high water content and a short storage period. Recalcitrant seeds germinate and quickly lost their viability when stored in the open air. It also needs low temperature in its storage process. Generally, recalcitrant seeds ripe within pod, covered by a watery, fleshy pulp and a watertight testa. In that case, the water content of recalcitrant seeds ranged between $50-70 \%$, and the embryos are $15 \%$ bigger than orthodox seeds and have no dormancy period (Copeland \& McDonald, 2001; Schmidt, 2007; Umarani et al ., 2015).
This situation makes recalcitrant seeds become easier to germinate (Daws et al., 2005), difficult to be stored.

In Indonesia, the expansion of cocoa planting farm areas is continuously carried out. The five biggest cocoa beans producing provinces are Southeast Sulawesi, Central Sulawesi, South Sulawesi, West Sulawesi, and West Sumatra (BPS, 2019) while the Indonesian Coffee and Cocoa Research Institute as the biggest producer of cocoa seeds in Indonesia is located in East Java. The distance between the expansion areas for cocoa plantations and seed producers 
and the increasing demand for cocoa seeds causing the cocoa seed storage technology to become urgent. Cocoa seeds can germinate in 3-4 days after harvested. Moreover, cocoa seeds in some clones will germinate inside pod on the tree when the harvest process is late (Rahardjo, 2011). The seed deterioration is affected by some factors such as water content, storage temperature, and oxygen content in the storage room (De-Vitis et al., 2020). Subsequently, cocoa seeds cannot be stored at high temperatures $\left(>30^{\circ} \mathrm{C}\right)$ and low temperatures $\left(<4^{\circ} \mathrm{C}\right)$ because it can reduce seed viability (Rahardjo, 1985; Anita-Sari et al., 2018). The viability of cocoa seeds can only survive for $5-7$ days at storage temperature $25-27^{\circ} \mathrm{C}$, humidity $55-75 \%$ and will germinate after 7-10 days (Pancaningtyas, 2015; Olaiya, 2016; Saajah \& Maalekuu, 2014). Cocoa seeds that pass the storage period will deteriorate assigned by the degradation of germination, the physical quality of seeds, and the abnormal growth of the seedlings. Storing of cocoa seeds for more than four weeks in vacuum and nonvacuum packaging will decrease their germination process (Anita-Sari et al., 2018). The storage of cocoa seeds in form of seed utilizing the media of moisture buffer materials such as charcoal powder (Soedarsono, 1985), rice husk ash (Rahardjo, 2012), and the modification of packaging (Anita-Sari et al., 2018) has been carried out but the results are still not satisfied. The character of cocoa seeds which are sensitive to storage temperature becomes the main obstacle.

Storing of seeds in form of cocoa pods can be an alternative to slow down the process of seed deterioration. Cocoa pod storage at room temperature $\left(28-30^{\circ} \mathrm{C}\right)$ can increase the seed acidity level after being kept for seven days (Hinneh et al., 2018). The high acidity will kill the embryo. Cocoa pod storage for a long time at room temperature allows fermentation to occur and decrease seed viability. Therefore, the storage process is better to be implemented at a controlled temperature. Rahardjo (2011) stated that cocoa seed storage inside pod can survive for 30 days at 15$21^{\circ} \mathrm{C}$ but its effect on seedling growth is still unknown. Besides, the range of storage temperature used is still significant, that is $6^{\circ} \mathrm{C}$. Storage of cocoa pods at low temperature may extend the storage period of seeds. This study used an air-conditioned room with a controlled temperature of $20 \pm 2^{\circ} \mathrm{C}$ and the observations were conducted until the nursery phase after the storage period. This study aimed to determine the effect of pod storage temperature and storage period on the pod shrinkage, seed water content, seed germination, and the cocoa seedling growth performance.

\section{MATERIALS AND METHODS}

This study was arranged in Plant Breeding Laboratory of the Indonesian Coffee and Cocoa Research Institute. Split-plot randomized design was used with storage temperature as main plot while pod storage period as the subplot. The storage temperature were $20 \pm 2^{\circ} \mathrm{C}$ (controlled temperature in an airconditioned room) and at $29 \pm 2^{\circ} \mathrm{C}$ (room temperature). The subplot consisted of five treatments, namely 0 (control), 3, 7, 14, and 30 days. Each combination of treatments consisted of five cocoa pods of Sulawesi 1 clone and repeated 3 times. Cocoa pods were harvested and then soaked for 10 minutes in mankozeb fungicide solution of $0.2 \%(\mathrm{w} / \mathrm{v})$, afterward was dried in air temperature for 2 hours. After that, the pods were packed using polyethylene plastic and stored.

After storage, the pods were evaluated according to the storage period by calculating the pod shrinkage percentage. Pod shrinkage percentage:

$$
\frac{m_{1}-m_{2}}{m_{1}} \times 100 \%
$$

$m_{1}$ is the weight of cocoa pods before storage; $\mathrm{m}_{2}$ is the weight of cocoa pods after storage. 
After that, the pod was split, the pulp were eliminated using sawdust, and peeled from the epidermis. The seeds were soaked in $0.2 \%(\mathrm{w} / \mathrm{v})$ mankozeb fungicide solution for 10 minutes. The cocoa seeds were drained, dried for 3 hours, and the moisture content was observed after the storage. Before sowing, the cocoa seeds were soaked in clean water overnight and sown in a $5 \mathrm{~cm} \times 5 \mathrm{~cm} \times 5 \mathrm{~cm}$ seedling pot. The study of cocoa seedlings used a completely randomized design with three replications (each replication contained 20 seeds). Cocoa seedlings were then evaluated at the age of 3 months after sowing.

Seed water content:

$$
\begin{gathered}
\mathrm{S}_{1}=\frac{w_{2}-w_{3}}{w_{2}-w_{1}} \times 100 \% \\
\mathrm{~S}_{2}=\frac{w_{3}-w_{4}}{w_{2}-w_{1}} \times 100 \% \\
S W C=S_{1}+S_{2}-\frac{S_{1}-S_{2}}{100}
\end{gathered}
$$

$\mathrm{S}_{1}$ is percentage of seed content lost on the first drying; $S_{2}$ is percentage of seed content lost in the second drying; $\mathrm{w}_{1}$ is the weight of preheated porcelain cup and cover $(\mathrm{g})$; $\mathrm{w}_{2}$ is the weight of the porcelain cup, cover, and cocoa seed before drying $(\mathrm{g}) ; \mathrm{w}_{3}$ is the weight of porcelain cup, cover, and cocoa seed after the first drying at the temperature of $130^{\circ} \mathrm{C}$ for 60 minutes $(\mathrm{g}) ; \mathrm{w}_{4}$ is the weight of the porcelain cup, cover, and cocoa seed after the second drying at the temperature of temperature of $130^{\circ} \mathrm{C}$ for 10 minutes $(\mathrm{g})$ (Rahardjo, 2011; Sudrajat et al., 2017).

Germination percentage:

$$
G P=\frac{n K N}{N} \times 100 \%
$$

$\mathrm{nKN}$ is the number of normal sprouts; $\mathrm{N}$ is the number of seedlings germinated (Sudrajat et al., 2007; Baliza et al., 2012).

Seedling height was measured from the base of the stem to the point of growth using a ruler $(\mathrm{cm})$; stem diameter was measured using a digital caliper ( $\mathrm{mm}$ ).
Number of leaves was counted the number of leaves that have perfectly opened.

Leaf area $\left(\mathrm{cm}^{2}\right)$ :

$$
\frac{w_{r f}}{w_{p p}} \times 100 \mathrm{~cm}^{2}
$$

$\mathrm{w}_{\mathrm{rf}}$ is the weight of leaf replica; $\mathrm{w}_{\mathrm{pp}}$ is the weight of leaf pattern $(10 \mathrm{~cm} \mathrm{x} 10 \mathrm{~cm})$ (Irwan \& Wicaksono, 2017).

Root length was measured using a ruler from the base of the root to the tip of the longest root $(\mathrm{cm})$.

Fresh weight is the total fresh weight of roots, stems and leaves (g).

Dry weight is the total dry weight of roots, stems, and leaves after oven at 65$85^{\circ} \mathrm{C}$ for 48 hours $(\mathrm{g})$, shoot and root ratio is the ratio of shoot dry weight and root dry weight.

Seedling quality index:

$$
\frac{w_{d}}{\frac{h}{s_{g}}+\frac{w_{s}}{w_{r}}}
$$

$\mathrm{w}_{\mathrm{d}}$ is total dry weight of roots, stems and leaves; $\mathrm{h}$ is seedling height; $\mathrm{s}_{\mathrm{g}}$ is stem diameter; $\mathrm{w}_{\mathrm{s}}$ is shoot dry weight; $w_{r}$ is root dry weight (Kurniaty et al., 2010).

The observational data were then analyzed using analysis of variance (ANOVA) in SAS 9.0 software and continued with Duncan's multiple range test if there was a significant difference.

\section{RESULTS AND DISCUSSION}

\section{Pod Shrinkage Percentage}

The results showed that storing cocoa pods at low temperature $\left(20^{\circ} \mathrm{C}\right)$ affect the quality of cocoa seedlings ( $\mathrm{p}<0.05)$. Interaction between cocoa pod storage temperature and storage period was significant (Table 1). It mean that storage temperature 
significantly affect pod shrinkage percentage, seed moisture content, and seed germination percentage $(\mathrm{p}<0.05)$. Pods stored at $20^{\circ} \mathrm{C}$ did not show a high shrinkage percentage eventhough stored for 30 days, whereas pods stored at $29^{\circ} \mathrm{C}$ had greater shrinkage percentage and directly proportional to the length of pod storage. The pod shrinkage when stored for 3 days was $8.2 \%$, but when stored for 30 days was $68.2 \%$ (Figure 1). Hinneh et al. (2018) reported that storing cocoa pods at room temperature can improve decomposition and pod putrefaction so that the color of the pod skin changes from yellow to black on $7^{\text {th }}$ day. This is due to the attack of microbes, the pod is damaged and decreased in freshness. In this research the highest weight loss was found $68.2 \%$ at room temperature storage.

Different results were shown by storing the cocoa pods at $20^{\circ} \mathrm{C}$. The pod shrinkage at the storage for $0,3,7,14$, and 30 days were $0.0 \%, 0.8 \%, 0.9 \%, 0.8 \%$, and $1.6 \%$, respectively (Figure 1). The pod shrinkage for 0 to 30 days did not show a significant difference therefore the freshness of the pod was still similar with the beginning of harvest. Temperature affects the biochemical processes in cocoa pods. The biological process was optimal at room temperature and decreased at the lower temperature. Storage at low temperatures is common for tropical and subtropical fruit because it can slow down the metabolic processes, suppress fruit damage, and keep fruits fresh (Chaudhary et al., 2017; Sun et al., 2018). Storing cocoa pods at low temperatures can inhibit the fermentation process, then the sugar content is still maintained. The storage at room temperature will cause cocoa pods to undergo fermentation and increase the acidity of the beans (Hinneh et al., 2018; Kone et al., 2020). The breakdown of sugar content in the beans during fermentation can affect seed germination.

Storing cocoa pods at $20^{\circ} \mathrm{C}$ for 30 days was able to keep pod skin fresh (small pod shrinkage percentage). In the fresh pod, the pulp is still attached (Hinneh et al., 2018). The pulp plays important role in delaying

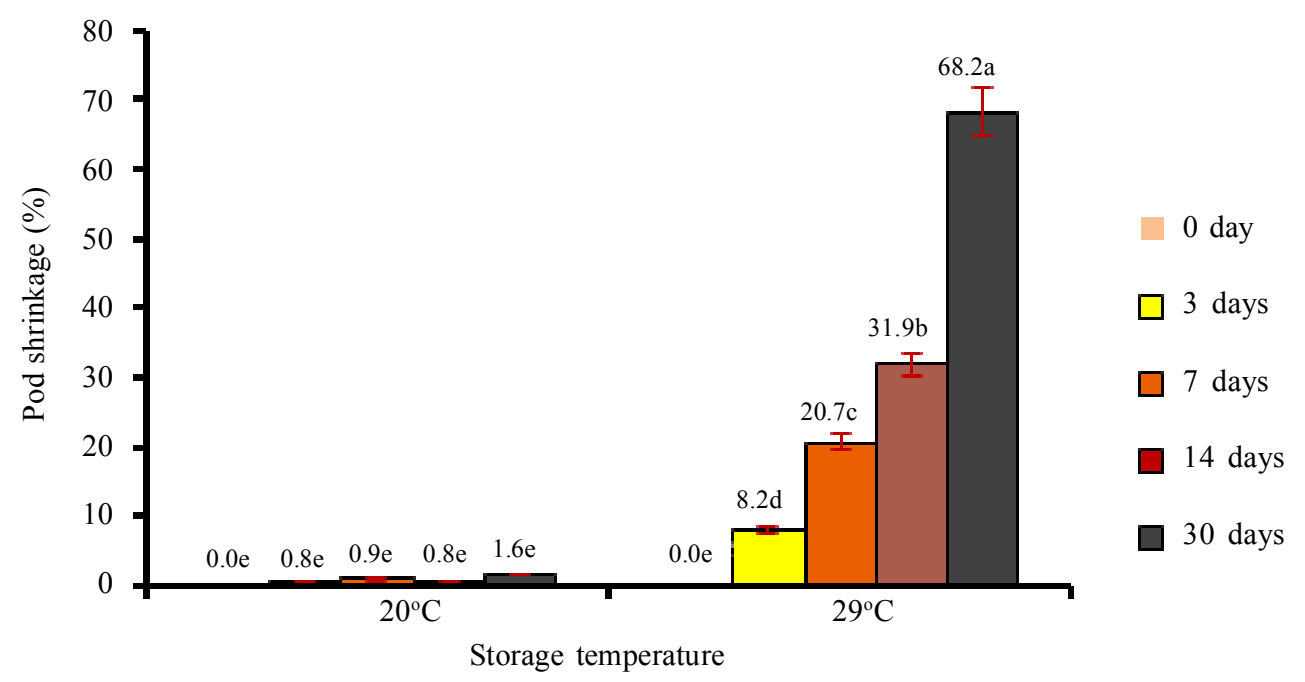

Figure 1. Pod shrinkage during storage period at controlled temperature $\left(20^{\circ} \mathrm{C}\right)$ and at room temperature $\left(29^{\circ} \mathrm{C}\right)$ 
Table 1. F-value of pod, seed quality and seedling performance

\begin{tabular}{|c|c|c|c|c|c|}
\hline Source of variability & $\mathrm{df}$ & Pod shrinkage & Seed water content & Germination & Seedling height \\
\hline Temperature (Temp.) & 1 & $4679.25 * *$ & $8.12 *$ & $93.53 *$ & $0.02 \mathrm{~ns}$ \\
\hline Replication & 2 & $6.63 \mathrm{~ns}$ & $0.02 \mathrm{~ns}$ & $55.97 \mathrm{~ns}$ & $0.97 \mathrm{~ns}$ \\
\hline Temp. * Replication & 2 & $4.71 \mathrm{~ns}$ & $0.14 \mathrm{~ns}$ & $16.31 \mathrm{~ns}$ & $2.22 \mathrm{~ns}$ \\
\hline Storage period & 4 & $1105.11 * *$ & $64.70 * *$ & $49.45 \mathrm{~ns}$ & $22.31 * *$ \\
\hline \multirow[t]{2}{*}{ Temp. * Storage period } & 4 & $1025.22 * *$ & $17.50 * *$ & $84.47 *$ & $9.34 *$ \\
\hline & & Stem diameter & Number of leaves & Leafarea & Root length \\
\hline Temperature (Temp.) & 1 & $0.11 *$ & $0.53 \mathrm{~ns}$ & $1598.28 *$ & $1.48 \mathrm{~ns}$ \\
\hline Replication & 2 & $0.01 \mathrm{~ns}$ & $0.30 \mathrm{~ns}$ & $186.36 \mathrm{~ns}$ & $0.17 \mathrm{~ns}$ \\
\hline Temp. * Replication & 2 & $0.01 \mathrm{~ns}$ & $0.03 \mathrm{~ns}$ & $135.17 \mathrm{~ns}$ & $4.21 *$ \\
\hline Storage period & 4 & $0.41 * *$ & $1.62 * *$ & $2794.57 * *$ & $3.79 *$ \\
\hline \multirow[t]{2}{*}{ Temp. * Storage period } & 4 & $0.05 *$ & $0.28 \mathrm{~ns}$ & $409.04 *$ & $0.91 \mathrm{~ns}$ \\
\hline & & Total fresh weight & Total dry weight & Shoot and root ratio & Seedling quality index \\
\hline Temperature (Temp.) & 1 & $1.21 * *$ & $0.10 * *$ & $5.77 *$ & $0.001 * *$ \\
\hline Replication & 2 & $0.01 \mathrm{~ns}$ & $0.00 \mathrm{~ns}$ & $0.27 \mathrm{~ns}$ & $0.000 \mathrm{~ns}$ \\
\hline Temp. * Replication & 2 & $0.08 \mathrm{~ns}$ & $0.01 \mathrm{~ns}$ & $1.82 \mathrm{~ns}$ & $0.000 \mathrm{~ns}$ \\
\hline Storage period & 4 & $1.96 * *$ & $0.09 * *$ & $1.70 \mathrm{~ns}$ & $0.001 * *$ \\
\hline Temp. $*$ Storage period & 4 & $0.37 * *$ & $0.02 *$ & $0.61 \mathrm{~ns}$ & $0.000 \mathrm{~ns}$ \\
\hline
\end{tabular}

Notes: $\mathrm{ns}=$ not significantly difference; $*=$ significant at $\alpha=0.05 ; * *=$ significant at $\alpha=0.01$.

seed germination inside the pod. The pulp has functions to stabilize the water potential around the seeds and prevent them from drought stress during storage (Adu et al., 2017). Storing cocoa pod at high temperatures for relatively long time causes drying of the pulps faster, so the deterioration of the seeds is also faster. Recalcitrant seeds are generally sensitive to low temperature and will damage and decreased viability at temperature range of $15-20^{\circ} \mathrm{C}$ (Schmidt, 2007).

\section{Seed Water Content}

The results showed that seed moisture content after storage was influenced by temperature and storage period of pods ( $p<0.05$ ). Cocoa seeds contain high moisture content after harvest, namely $51.3 \%$ and will decrease if being stored for a long period. After stored for 30 days at $20^{\circ} \mathrm{C}$ the moisture decreased to $45.0 \%$ and $44.2 \%$ at $29^{\circ} \mathrm{C}$ (Figure 2). The length of pod storage and storage temperature significantly affect seed moisture. Storage at $20^{\circ} \mathrm{C}$ and $29^{\circ} \mathrm{C}$ was able to maintain the seed moisture content in the range of $40-55 \%$
(Figure 2) and still met the quality standards of cocoa seeds, namely 30-40\% (Ministry of Agriculture, 2013). The similar results were reported by Anita-Sari et al. (2018) for storing cocoa seeds at $15^{\circ} \mathrm{C}, 25^{\circ} \mathrm{C}$, and $30^{\circ} \mathrm{C}$. The moisture content of cocoa seeds after storing for more than 3 weeks still ranged at $40.37-42.77 \%$. Recalcitrant seeds require high moisture content during storage (30-50\%) for a short period of time (Schmidt, 2007). Cocoa pod storage for 30 days at the temperature of $20^{\circ} \mathrm{C}$ and $29^{\circ} \mathrm{C}$ was still able to maintain the moisture content of the seeds at $40-50 \%$. Seeds that are sensitive to the drying possess the potential to germinate quickly because of the limited imbibition process (Daws et al., 2005). Storing cocoa seed in the form of pods and seeds at low temperatures can slow down the process of losing moisture in the seeds (Anita-Sari et al., 2018). Seed water content is closely related to the imbibition process and plays significant role in hormone activation. Water content that is tolerant of storage period in recalcitrant seeds is very essential to observe because it is closely related to seed viability and storage period. 


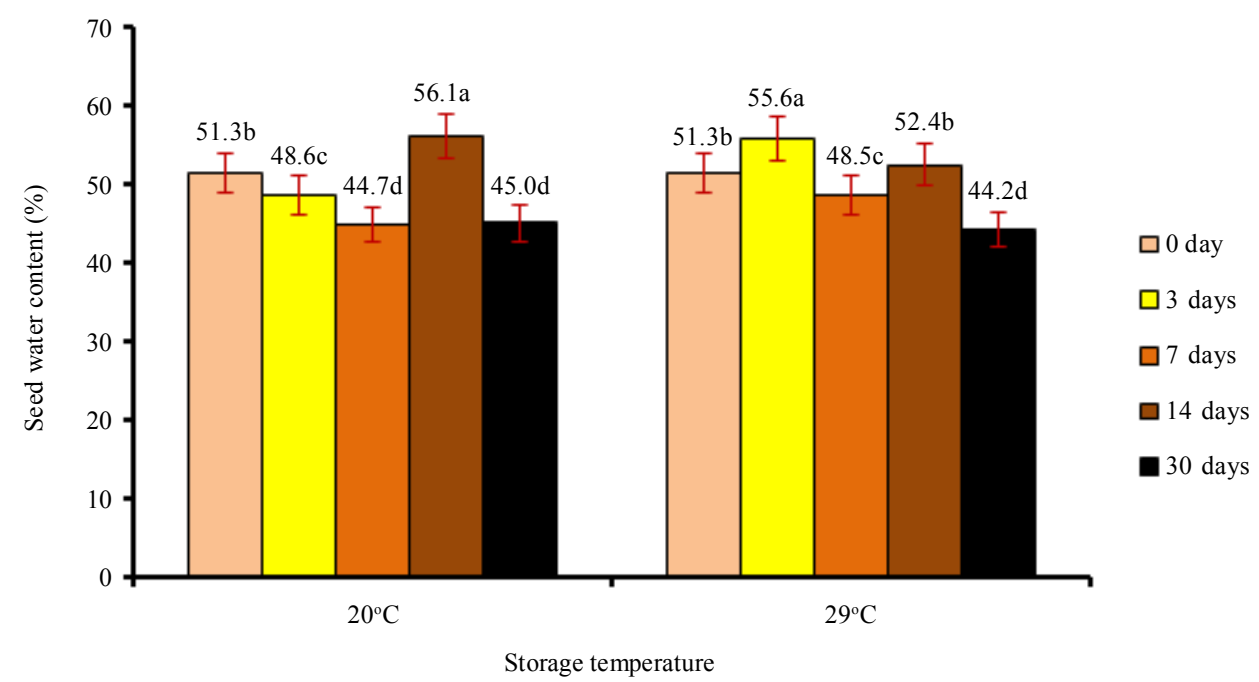

Figure 2. Seed water content after storage at controlled temperature $\left(20^{\circ} \mathrm{C}\right)$ and room temperature $\left(29^{\circ} \mathrm{C}\right)$

\section{Germination Percentage}

The analysis showed that seed germination percentage were significantly influenced by temperature and pod storage period $(\mathrm{p}$ $<0.05$ ). Storage up to 30 days at $20^{\circ} \mathrm{C}$ was still able to maintain seed germination percentage at $93.2 \%-98.7 \%$, while storage at $29^{\circ} \mathrm{C}$ for 30 days causes seed germination decrease to $83.4 \pm 8.7 \%$ (Figure 3 ). Pod storage at $29^{\circ} \mathrm{C}$ for 14 days was able to maintain germination of $96.0 \%$. The germination percentage of cocoa seeds stored in the form of pods was better than the storage in the form of seeds. Anita-Sari et al. (2018) reported that cocoa seeds stored at $\pm 25^{\circ} \mathrm{C}$ were only can maintain seed viability above $90 \%$ for two weeks while storing at temperature of $\pm 15^{\circ} \mathrm{C}$ result in faster seed deterioration. According to Sobari et al. (2020), storing cocoa seeds at room temperature can maintain the growth $>80 \%$ for only 1 week. Meanwhile, storing cocoa pods at $20^{\circ} \mathrm{C}$ can maintain for 30 days. This temperature has begun to be used for storing forest plant seeds, i.e. Shorea javanica can germinate $>80 \%$ after being stored for 30 days at the same temperature (Umarani et al., 2015). The growth of coffee seedlings is still $>85 \%$ after six months of storage (Wibowo et al., 2020). Storing cocoa pods at low temperatures can keep the pulps fresh, so, seed deterioration does not occur. On contrary, it will stimulate the good germination of cocoa seeds.

\section{Seedling Growth}

The result showed that storage temperature and storage period caused significant effect on seedling height, stem diameter, and leaf area $(\mathrm{p}<0.05)$. Interaction between both treatments showed significant results (Table 1). Storage at $29^{\circ} \mathrm{C}$ showed highest seedling height after being stored for 3 days and 14 days i.e. $23.2 \mathrm{~cm}$ and $24.0 \mathrm{~cm}$ respectively. Storage at $20^{\circ} \mathrm{C}$ showed the highest seedling height after 14 days and 30 days i.e. $23.07 \mathrm{~cm}$ and $23.37 \mathrm{~cm}$ respectively. Cocoa pod stored at $20^{\circ} \mathrm{C}$ also showed good stem diameter development, especially after storage for 14 days $(2.65 \mathrm{~mm})$ and 30 days $(2.86 \mathrm{~mm})$. Sub- 


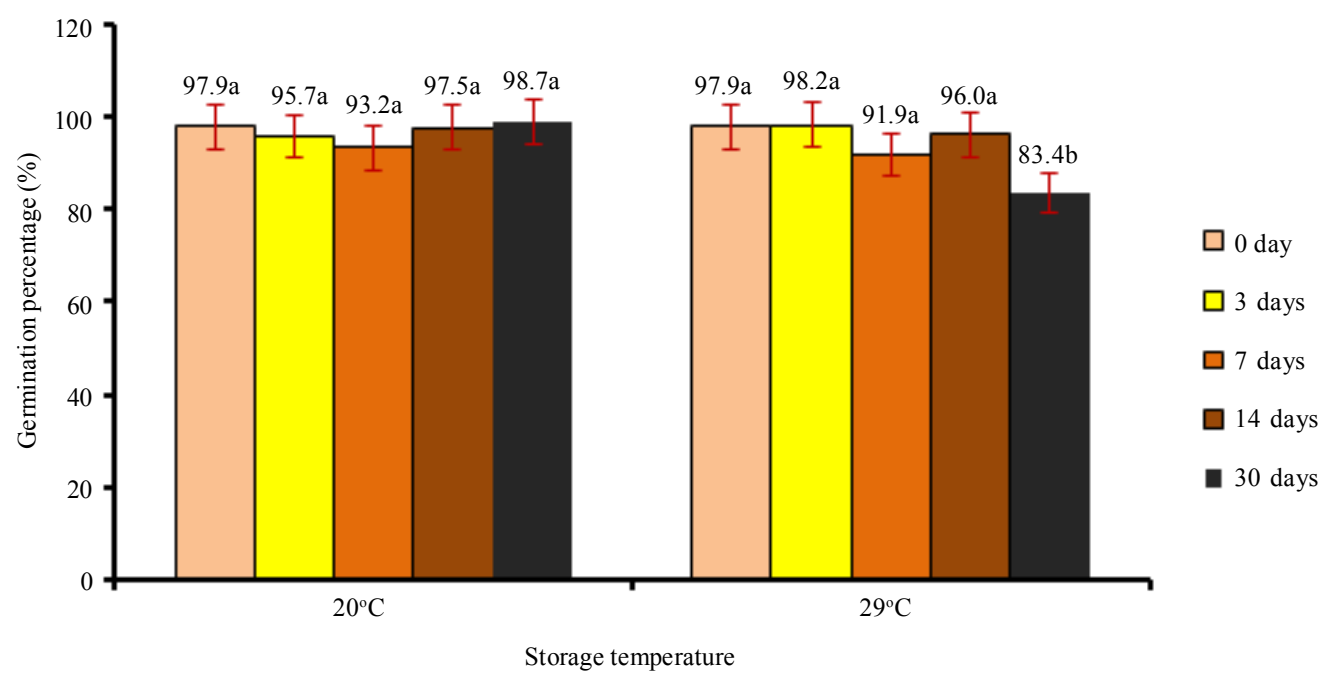

Figure 3. Germination percentage of cocoa seed after storage period at controlled temperature $\left(20^{\circ} \mathrm{C}\right)$ and room temperature $\left(29^{\circ} \mathrm{C}\right)$

sequently, at temperature $29^{\circ} \mathrm{C}$, the best development of stem diameter for cocoa seedlings produced by storing the pods for 3,7 , and 14 days i.e. $2.78 \mathrm{~mm}, 2.83 \mathrm{~mm}$, and $2.83 \mathrm{~mm}$, respectively. In line with that, storing cocoa pods at $20^{\circ} \mathrm{C}$ for 30 days can also produce a leaf area of $159.1 \mathrm{~cm}$. Therefore, it was not significantly different with storing at $29^{\circ} \mathrm{C}$ for 3 days $\left(155.4 \mathrm{~cm}^{2}\right), 7$ days $\left(160.5 \mathrm{~cm}^{2}\right)$, and 30 days $\left(160.5 \mathrm{~cm}^{2}\right)$.

The number of leaves and root length of cocoa seedlings were not significantly affected by temperature and pod storage period (Table 1). Both growth variables were more influenced by pod storage period. Pods stored at $20^{\circ} \mathrm{C}$ and $29^{\circ} \mathrm{C}$ were able to produce seedlings with 5-6 leaves and the root length of $7.51 \mathrm{~cm}$ and $7.95 \mathrm{~cm}$ (Table 2). Pod storage for 7 days was able to produce seedlings with an average number of leaves $6-7$, not significantly different with storing pods for 30 days. However, storing pods for 7 days was also able to produce seeds with the longest roots, which was $8.85 \mathrm{~cm}$.
Storage temperature and period of cocoa pods influenced plant growth during the seedling phase $(\mathrm{p}<0.05)$. Pod storage at $20^{\circ} \mathrm{C}$ for 30 days showed good seedling growth better than of storaged at $29^{\circ} \mathrm{C}$ for 30 days on the parameters of seedling height, stem diameter, and root length. Pod storage at this temperature also suffered less damage, therefore to maintain the good physical quality of the seeds. Storage at room temperature, for 5 days showed the best appearance of plant height (Saajah \& Maalekuu, 2014). Pod storage at $20^{\circ} \mathrm{C}$ for 30 days was able to produce seedlings with good seedling height, stem diameter, and leaf area. Pod storage at $29^{\circ} \mathrm{C}$ for 14 days was able to produce the best growth of seedling height and stem diameter. The best number of leaves and root length was produced by storing the pod for 7 days at $29^{\circ} \mathrm{C}$. Cocoa seeds harvested from the healthy pods can only have good viability for 3 weeks after harvesting (Amoako et al., 2019; Saajah \& Maalekuu, 2014). In this study, cocoa pod storage at room temperature will produce good seedling growth if stored only for 14 days. 
Table 2. Several parameter of cocoa seedling growth after 3 months old

\begin{tabular}{|c|c|c|c|c|c|}
\hline & Seedling height $(\mathrm{cm})$ & Stem diameter $(\mathrm{mm})$ & Number of leaves & Leaf area $\left(\mathrm{cm}^{2}\right)$ & Root length $(\mathrm{cm})$ \\
\hline \multicolumn{6}{|c|}{ Temperature } \\
\hline $20^{\circ} \mathrm{C}$ & $20.97 \mathrm{a}$ & $2.54 \mathrm{~b}$ & $5.7 \mathrm{a}$ & $131.36 \mathrm{~b}$ & $7.51 \mathrm{a}$ \\
\hline $29^{\circ} \mathrm{C}$ & $20.94 \mathrm{a}$ & $2.67 \mathrm{a}$ & $5.9 \mathrm{a}$ & $145.96 \mathrm{a}$ & $7.95 \mathrm{a}$ \\
\hline \multicolumn{6}{|c|}{ Storage period } \\
\hline 0 day $(\mathrm{k})$ & $18.91 \mathrm{c}$ & $2.15 \mathrm{a}$ & $5.3 \mathrm{c}$ & $102.32 \mathrm{c}$ & $6.60 \mathrm{c}$ \\
\hline 3 days & $21.63 \mathrm{~b}$ & $2.66 \mathrm{a}$ & $5.7 \mathrm{bc}$ & $144.43 \mathrm{~b}$ & $7.66 \mathrm{bc}$ \\
\hline 7 days & $19.19 \mathrm{c}$ & $2.67 \mathrm{a}$ & $6.5 \mathrm{a}$ & $140.43 \mathrm{~b}$ & $8.85 \mathrm{a}$ \\
\hline 14 days & $23.56 \mathrm{a}$ & $2.74 \mathrm{a}$ & $5.3 \mathrm{c}$ & $146.31 \mathrm{ab}$ & $7.74 \mathrm{ab}$ \\
\hline \multirow[t]{2}{*}{30 days } & $21.54 \mathrm{~b}$ & $2.80 \mathrm{a}$ & $6.2 \mathrm{ab}$ & $159.81 \mathrm{a}$ & $7.79 \mathrm{ab}$ \\
\hline & Fresh weight (g) & Dry weight (g) & Shoot/root ratio & Seedling quality index & \\
\hline \multicolumn{6}{|c|}{ Temperature } \\
\hline $20^{\circ} \mathrm{C}$ & $2.70 \mathrm{~b}$ & $0.64 \mathrm{~b}$ & $6.27 \mathrm{~b}$ & $0.04 \mathrm{~b}$ & \\
\hline $29^{\circ} \mathrm{C}$ & $3.10 \mathrm{a}$ & $0.75 \mathrm{a}$ & $7.15 \mathrm{a}$ & $0.05 \mathrm{a}$ & \\
\hline \multicolumn{6}{|c|}{ Storage period } \\
\hline 0 day $(\mathrm{k})$ & $1.91 \mathrm{c}$ & $0.51 \mathrm{c}$ & $7.39 \mathrm{a}$ & $0.06 \mathrm{a}$ & \\
\hline 3 days & $3.14 \mathrm{ab}$ & $0.79 \mathrm{a}$ & $5.99 \mathrm{a}$ & $0.03 \mathrm{~b}$ & \\
\hline 7 days & $2.97 \mathrm{~b}$ & $0.64 \mathrm{~b}$ & $6.79 \mathrm{a}$ & $0.05 \mathrm{a}$ & \\
\hline 14 days & $3.13 \mathrm{ab}$ & $0.78 \mathrm{a}$ & $6.43 \mathrm{a}$ & $0.05 \mathrm{a}$ & \\
\hline 30 days & $3.37 \mathrm{a}$ & $0.78 \mathrm{a}$ & $6.96 \mathrm{a}$ & $0.05 \mathrm{a}$ & \\
\hline
\end{tabular}

\section{Seedling Quality}

The variables of seedlings quality consist of fresh weight, dry weight, root/shoot ratio, and seedling quality index. Fresh weight and dry weight of cocoa seedlings were significantly affected by pod storage temperature, pod storage period, and interaction of both treatments $(p<0.05)$. High fresh weight was produced by storing the pods for 30 days $(3.48 \mathrm{~g})$ at temperature $20^{\circ} \mathrm{C}$ and followed by the storage for 3 days $(3.61 \mathrm{~g}), 7$ days (3.35 g), 14 days (3.39 g), and 30 days (3.26 g) at $29^{\circ} \mathrm{C}$. The highest dry weight was obtained from storing at $29^{\circ} \mathrm{C}$ for three days $(0.91 \mathrm{~g})$.

The interaction between temperature and storage period of pods did not significantly affect root/shoot ratio of cocoa seedlings (Table 1). The shoot root biomass ratio of cocoa seeds was only significantly affected by the pod storage temperature $(\mathrm{p}<0.05)$. Pods storage at the temperature of $20^{\circ} \mathrm{C}$ had a root/shoot ratio of 6.27. Meanwhile, at the temperature of $29^{\circ} \mathrm{C}$, it was 7.15 . Pod storage at the temperature of $20^{\circ} \mathrm{C}$ for 30 days, 7 days, and 0 days $(7.58 ; 7.35 ; 7.39$, respectively) had the highest shoot root ratio. The shoot root ratio of seedlings from pod storage at $29^{\circ} \mathrm{C}$ for seven days, 14 days, and 30 days were almost the same $(6.23 ; 6.20 ; 6.35)$.

Seedling quality index was not affected by interaction between temperature and pod storage period. Storing the pods at $20^{\circ} \mathrm{C}$ showed quality index 0.04 , meanwhile, at $29^{\circ} \mathrm{C}$, was 0.05 . Cocoa pod storage period did not significantly affect seedling quality index which for 3 days at $29^{\circ} \mathrm{C}$ was 0.07 , but not significantly different from storing cocoa for 7,14 , and 30 days $(0.06)$ at the same temperature (Table 3 ). Seedling quality index from cocoa pod storage for 14 days and 30 days at $20^{\circ} \mathrm{C}$ was 0.05 , which was better than the pod storage for 3 and 7 days at the same temperature. The decline in the quality of cocoa seedlings from storing the pods for 14 days and 30 days was not significant, which means this temperature had the potential to be a recommendation for storing cocoa pods.

Cocoa pod storage at different temperatures significantly affect pod shrinkage percentage, seed moisture content, germination percentage, and seedling quality performance. 
The differences in storage temperature had a significant effect on the stem diameter and leaf area. In the seedling growth, cocoa plants rely on cotyledons which are rich in food stores. The growing medium will begin to affect growth after the cocoa seedlings 4-6 months old or after the cotyledons are released from the plant stems (Anthonio et al., 2018; Amoako et al., 2019). Root character is controlled by genetic factors (Lynch et al., 2012) but their phenotypic traits can change in response to environmental conditions. Environmental factors that have strong influence on root growth are water content and availability of nutrients in the growing medium. Shoot/root biomass ratio shows the growth ratio between the shoot and roots. The higher the shoot root ratio, the greater development of the shoot. The mechanism of the shoot root ratio is affected by environmental conditions and controlled by hormonal factors. Plants will stop shoot growth if there is drought stress, soil compaction occurs, or poorly soil aeration levels.

\section{Pod Storage Correlation Effect}

Correlation analysis aims to determine the closeness relationship of the cocoa storage period and the observed variables. The analysis showed that the pod storage at $20^{\circ} \mathrm{C}$ was significantly positively correlating $(\mathrm{p}<0.05)$ with the pod shrinkage, seedling height, stem diameter, number of leaves, leaf area, seedlings fresh weight, seedlings dry weight, and seedling quality index (Table 4). The cocoa pod storage at $29^{\circ} \mathrm{C}$ was significantly negative correlating with moisture content and germination percentage $(\mathrm{p}<0.05)$ and positive correlated with pod shrinkage. Two observation variables have strong relationship if the correlation coefficient value is $>0.5-0.75$ and very

Table 3. Interaction between temperature and pod storage period on the cocoa seedling performance

\begin{tabular}{|c|c|c|c|c|c|c|}
\hline \multirow{3}{*}{ Storage period } & \multicolumn{6}{|c|}{ Temperature } \\
\hline & \multicolumn{2}{|c|}{ Seedling height $(\mathrm{cm})$} & \multicolumn{2}{|c|}{ Stem diameter $(\mathrm{mm})$} & \multicolumn{2}{|c|}{ Number of leaves } \\
\hline & $20^{\circ} \mathrm{C}$ & $29^{\circ} \mathrm{C}$ & $20^{\circ} \mathrm{C}$ & $29^{\circ} \mathrm{C}$ & $20^{\circ} \mathrm{C}$ & $29^{\circ} \mathrm{C}$ \\
\hline 0 days $(\mathrm{k})$ & $18.91 \mathrm{~b}$ & $18.91 \mathrm{~b}$ & $2.15 \mathrm{~d}$ & $2.15 \mathrm{~d}$ & $5.3 \mathrm{c}$ & $5.3 \mathrm{c}$ \\
\hline 3 days & $20.05 \mathrm{~b}$ & $23.21 \mathrm{a}$ & $2.55 \mathrm{bc}$ & $2.78 \mathrm{a}$ & $5.7 \mathrm{bc}$ & $5.7 \mathrm{bc}$ \\
\hline 7 days & $19.53 \mathrm{~b}$ & $18.84 \mathrm{~b}$ & $2.51 \mathrm{c}$ & $2.83 \mathrm{a}$ & $6.0 \mathrm{bc}$ & $7.0 \mathrm{a}$ \\
\hline 14 days & $23.07 \mathrm{a}$ & $24.04 \mathrm{a}$ & $2.65 \mathrm{abc}$ & $2.83 \mathrm{a}$ & $5.3 \mathrm{c}$ & $5.3 \mathrm{c}$ \\
\hline \multirow[t]{2}{*}{30 days } & $23.37 \mathrm{a}$ & $19.70 \mathrm{~b}$ & $2.86 \mathrm{a}$ & $2.74 \mathrm{ab}$ & $6.0 \mathrm{bc}$ & $6.3 \mathrm{ab}$ \\
\hline & \multicolumn{6}{|c|}{ Temperature } \\
\hline \multirow[t]{2}{*}{ Storage period } & \multicolumn{2}{|c|}{ Leaf area $\left(\mathrm{cm}^{2}\right)$} & \multicolumn{2}{|c|}{ Root length $(\mathrm{cm})$} & \multicolumn{2}{|c|}{ Fresh weight $(\mathrm{g})$} \\
\hline & $20^{\circ} \mathrm{C}$ & $29^{\circ} \mathrm{C}$ & $20^{\circ} \mathrm{C}$ & $29^{\circ} \mathrm{C}$ & $20^{\circ} \mathrm{C}$ & $29^{\circ} \mathrm{C}$ \\
\hline 0 days $(\mathrm{k})$ & $102.32 \mathrm{~d}$ & $102.32 \mathrm{~d}$ & $6.60 \mathrm{c}$ & $6.60 \mathrm{c}$ & $1.91 \mathrm{c}$ & $1.91 \mathrm{c}$ \\
\hline 3 days & $133.43 \mathrm{bc}$ & $155.42 \mathrm{a}$ & $6.84 \mathrm{bc}$ & $8.48 \mathrm{ab}$ & $2.66 \mathrm{~b}$ & $3.61 \mathrm{a}$ \\
\hline 7 days & $120.62 \mathrm{~cd}$ & $160.25 \mathrm{a}$ & $8.73 \mathrm{a}$ & $8.96 \mathrm{a}$ & $2.59 \mathrm{~b}$ & $3.35 \mathrm{a}$ \\
\hline 14 days & $141.29 \mathrm{ab}$ & $151.33 \mathrm{ab}$ & $7.38 \mathrm{abc}$ & $8.10 \mathrm{abc}$ & $2.87 \mathrm{~b}$ & $3.39 \mathrm{a}$ \\
\hline \multirow[t]{2}{*}{30 days } & $159.14 \mathrm{a}$ & $160.48 \mathrm{a}$ & $7.98 \mathrm{abc}$ & $7.60 \mathrm{abc}$ & $3.48 \mathrm{a}$ & $3.26 \mathrm{a}$ \\
\hline & & & $\mathrm{Te} 1$ & & & \\
\hline \multirow[t]{2}{*}{ Storage period } & \multicolumn{2}{|c|}{ Dry weight (g) } & \multicolumn{2}{|c|}{ Shoot/root ratio } & \multicolumn{2}{|c|}{ Seedling quality index } \\
\hline & $20^{\circ} \mathrm{C}$ & $29^{\circ} \mathrm{C}$ & $20^{\circ} \mathrm{C}$ & $29^{\circ} \mathrm{C}$ & $20^{\circ} \mathrm{C}$ & $29^{\circ} \mathrm{C}$ \\
\hline 0 days $(\mathrm{k})$ & $0.51 \mathrm{~d}$ & $0.51 \mathrm{~d}$ & $7.39 \mathrm{a}$ & $7.39 \mathrm{a}$ & $0.03 \mathrm{e}$ & $0.03 \mathrm{e}$ \\
\hline 3 days & $0.66 \mathrm{c}$ & $0.91 \mathrm{a}$ & $6.78 a b$ & $5.20 \mathrm{~b}$ & $0.05 \mathrm{bcd}$ & $0.07 \mathrm{a}$ \\
\hline 7 days & $0.54 \mathrm{~d}$ & $0.74 \mathrm{bc}$ & $7.35 \mathrm{a}$ & $6.23 \mathrm{ab}$ & $0.04 \mathrm{de}$ & $0.06 \mathrm{abc}$ \\
\hline 14 days & $0.72 \mathrm{bc}$ & $0.83 a b$ & $6.65 \mathrm{ab}$ & $6.20 \mathrm{ab}$ & $0.05 \mathrm{bcd}$ & $0.06 \mathrm{abc}$ \\
\hline 30 days & $0.77 \mathrm{bc}$ & $0.78 \mathrm{~b}$ & $7.58 \mathrm{a}$ & $6.35 \mathrm{ab}$ & $0.05 \mathrm{bcd}$ & $0.06 \mathrm{abc}$ \\
\hline
\end{tabular}

Notes: Means of each variable with the same letter are not significantly different based on Duncan's multiple range test at $\alpha=$ $5 \% ;(\mathrm{k})=$ control 
Table 4. Correlation coefficient of storage periods at two levels of temperature and pod shrinkage, water content, germination percentage, and growth performance of cocoa seedlings

\begin{tabular}{|c|c|c|c|c|c|}
\hline & & Pod shrinkage & Seed water content & $\begin{array}{l}\text { Germination } \\
\text { percentage }\end{array}$ & Seedling height \\
\hline \multirow[t]{3}{*}{ Storage temperature } & $20^{\circ} \mathrm{C}$ & $0.83 * *$ & -0.26 & 0.22 & $0.80^{* *}$ \\
\hline & $29^{\circ} \mathrm{C}$ & $0.99 * *$ & $-0.75^{*}$ & $-0.73 * *$ & -0.01 \\
\hline & & Stem diameter & Number of leaves & Leafarea & Root length \\
\hline \multirow[t]{3}{*}{ Storage temperature } & $20^{\circ} \mathrm{C}$ & $0.81 * *$ & $0.67^{*}$ & $0.82 * *$ & 0.31 \\
\hline & $29^{\circ} \mathrm{C}$ & 0.40 & 0.32 & 0.48 & 0.01 \\
\hline & & Fresh weight & Dry weight & $\begin{array}{l}\text { Shoot and } \\
\text { root ratio }\end{array}$ & $\begin{array}{c}\text { Seedling } \\
\text { quality index }\end{array}$ \\
\hline \multirow[t]{2}{*}{ Storage temperature } & $20^{\circ} \mathrm{C}$ & $0.89 * *$ & $0.79 * *$ & 0.13 & $0.64 *$ \\
\hline & $29^{\circ} \mathrm{C}$ & 0.35 & 0.28 & -0.04 & 0.31 \\
\hline
\end{tabular}

Notes: $*=$ significantly at $\alpha=0.05 ; * *=$ significantly at $\alpha=0.01$.

strong if the correlation coefficient value is $>0.75-1$ (Aqil \& Efendi, 2015). The correlation between cocoa storage at $20^{\circ} \mathrm{C}$ with seedling height, stem diameter, leaf area, fresh weight, and dry weight of cocoa seedlings was strong because the correlation coefficient was $>0.75$ (Table 4). Meanwhile, in pod storage at $29^{\circ} \mathrm{C}$, the relationship between cocoa storage period and moisture content and germination percentage was also significant. The longer the cocoa pod storage period at $29^{\circ} \mathrm{C}$, the faster decrease the moisture content and germination percentage of the seedlings and higher pod shrinkage percentage. The negative coefficient value between the storage period and seed germination also occurs in the storage of cocoa seeds (Sobari et al., 2020). Pod shrinkage will still occur if the pod stored at $20^{\circ} \mathrm{C}$ and $29^{\circ} \mathrm{C}$ (the correlation coefficients were 0.83 and 0.99 , respectively) even though it is smaller at $20^{\circ} \mathrm{C}$.

Storing cocoa pods is very useful for extending the storage period of seeds. Cocoa pod storage at room temperature for 14 days can maintain good seedling quality (seedling growth $>95 \%$; the moisture content of $52.40 \%$; seedling height $24.04 \mathrm{~cm}$; stem diameter $2.83 \mathrm{~mm}$; root length $8.10 \mathrm{~cm}$ ). The storage of cocoa pods is suitable for the distribution of seeds in a wide range and takes 1-2 weeks. Storing for too long at room temperature will cause the color to become darker. Liquid pulp of the cocoa dries up and has the potential to interfere seed germination. Storing pods at controlled temperatures $\left(20^{\circ} \mathrm{C}\right)$ can extend the storage period of cocoa seeds. Storing cocoa pods at temperature of $20^{\circ} \mathrm{C}$ for 30 days is able to produce seeds with highest values in germination percentage, height, stem diameter, leaf area, fresh weight, and shoot root ratio of seedlings.

\section{CONCLUSIONS}

Storing of cocoa pods at $20^{\circ} \mathrm{C}$ for 30 days can maintain high seed germination $(98.7 \%)$ and seed water content (45\%) and low pod shrinkage percentage (1.6\%). Storing of cocoa pods at $29^{\circ} \mathrm{C}$ can also maintain the high level of seed water content $(44.2 \%)$ but decreased the seed germination (83.4\%) and increased pod shrinkage (68.2\%). Storing cocoa pods at $29^{\circ} \mathrm{C}$ for 14 days and at $20^{\circ} \mathrm{C}$ for 30 days can produce high-quality of seedlings in terms of seedling height, stem diameter, and root length. Storing of cocoa pod can be used as an alternative to extend the seed storage period of cocoa pods at room temperature $\left(29^{\circ} \mathrm{C}\right)$ can be used for 14 days however at controlled temperature can be for 30 days. 


\section{ACKNOWLEDGEMENTS}

The authors would like to thank to Fraizal Romadani, Heny Suryani, and Dewi Yuliatin for the assistance and participation in this study.

\section{REFERENCES}

Adu, M.O.; T. Cobbinah; P.A. Asare; D.O. Yawson \& K.J. Taah (2017). Demucilaging freshly stored seeds of cocoa (Theobroma cacao L.) improves seedling emergence and growth. Journal of Botany, 2017, $1-10$.

Amoako, P.K.; C. Awinsom \& Y. Sarfo (2019). Growth performance of cocoa (Theobroma cacao) hybrid seeds in different media. Trends Applied Science Research, 14(2), 130-135.

Anita-Sari, I.; B. Setyawan; F. Nur'Aini \& A.W. Susilo (2018). Germination and water content of cocoa seeds after storage treatments. Pelita Perkebunan, 34(3), 146-155.

Anthonio, M.M.; E.Y. Boampong; F.N. Coleman \& F.A. Anthonio (2018). The impact of different growth media on cocoa (Theobroma cacao L.) seedling. Journal of Energy and Natural Resource Management, 4(2), 56-61.

Aqil, M. \& R. Efendi (2015). Aplikasi SPSS dan SAS untuk Perancangan Percobaan. Absolute Media. Bantul, Yogyakarta.

Baliza, D.P.; F. Caixeta; E.V.R.V. Pinho; R.L. da Cunha; D.C. Martins \& S.D.V.F. da Rosa (2012). Physiological quality of coffee seeds produced under different levels of solar radiation and maturation stages. Revista Brasileira de Sementes, 34(3), 416-423.

BPS (2019). Statistik Kakao Indonesia 2019. Badan Pusat Statistik. Jakarta, Indonesia.

Chaudhary, P.; X. Yu; G.K. Jayaprakasha \& B.S. Patil (2017). Influence of storage temperature and low-temperature conditioning on the levels of health-promoting compounds in Rio Red grapefruit. Food Science and Nutrition, 5(3), 545-553.

Copeland, L.O. \& M.B. McDonald (2001). Principles of Seed Science and Technology. $4^{\text {th }}$ Edition. Springer Science and Business Media. New York, USA.

Daws, M.I.; N.C. Garwood \& H.W. Pritchard (2005). Traits of recalcitrant seed in a semi-deciduos tropical forest in Panama: Some ecological implications. Functional Ecology, 19(5), 874-885.

De-Vitis, M.; F.R. Hay, J.B. Dickie; C. Trivedi; J. Choi $\&$ R. Fiegener (2020). Seed storage: Maintaining seed viability and vigor for restoration use. The Journal of the Society for Ecological Restoration, 28(3), 1-7.

Hinneh, M.; E. Semanhyia;D.V.deWalle; A.D. Winne; D.A.T. Sosa; G.L.L. Scalone; B.D. Meulenaer; K. Messens; J.V. Durme; E.O. Afoakwa; L.D. Cooman \& K. Dewettinck (2018). Assessing the influence of pod storage on sugar and free amino acid profiles and the implications on some maillard reaction related flavor volatiles in Forastero cocoa beans. Food Research International, 111, 607-620.

Irwan, A.W. \& F.Y. Wicaksono (2017). Perbandingan pengukuran luas daun kedelai dengan metode gravimetri, regresi dan scanner. Jurnal Kultivasi, 16(3), 425-429.

Kone, K.M.; B.J. Assi-Clair; A.D.D. Kouassi; A.K. Yao; L. Ban-Koffi; N. Durand; M. Lebrun; I. Maraval; R. Bonlanger \& T.S. Guehi (2020). Pod storage time and spontaneous fermentation treatments and their impact on the generation of cocoa flavour precursor compounds. International Journal of Food Science and Technologi, 2020, 1-14.

Kurniaty, R.; B. Budiman \& M. Suartana (2010). Pengaruh media dan naungan terhadap mutu bibit suren (Toona sureni MERR.). Jurnal Penelitian Tanaman Hutan, 7(2), 77-83.

Lynch, J.; P. Marschner \& Z. Rengel (2012). Effect of internal and external factors on root growth and development. p. 331-346. In: 
Marschner's Mineral Nutrition of Higher Plants. Third Edition ( P. Marschner, Ed). Elsevier Ltd. San Diego, USA.

Ministry of Agriculture (2013). Peraturan Menteri Pertanian No. 90: Standar Operasional Prosedur Penetapan Kebun Sumber Benih. Sertifikasi Benih. dan Evaluasi Kebun Sumber Benih Tanaman Kakao (Theobroma cocoa L.). Kementerian Pertanian Republik Indonesia. Jakarta, Indonesia.

Olaiya, A.O. (2016). Growth and development of cacao (Theobroma cacao L.) seedlings in the nursery as influenced by pod maturity and retaining period after harvesting. Nigerian Journal of Ecology, 15(1), 19-23.

Pancaningtyas, S. (2015). Seed coating benih kakao untuk meningkatkan umur simpan benih kakao. Warta Pusat Penelitian Kopi dan Kakao Indonesia, 27(2), 14-18.

Rahardjo, P. (1985). Beberapa faktor yang berpengaruh terhadap daya hidup benih coklat. Menara Perkebunan, 49, 142-147.

Rahardjo, P. (2011). Menghasilkan Benih dan Bibit Kakao Unggul. Penebar Swadaya. Jakarta, Indonesia.

Rahardjo, P. (2012). Pengaruh pemberian abu sekam padi sebagai bahan desikan pada penyimpanan benih terhadap daya tumbuh dan pertumbuhan bibit kakao. Pelita Perkebunan, 28(2), 91-99.

Saajah, J.K. \& B.K. Maalekuu (2014). Determination of postharvest pod storage on viability and seedling growth performance of cocoa (Theobroma cacao L.) in the nursery. Journal of Agricultural Science, 6(4), 77-90.

Schmidt, L. (2007). Tropical Forest Seed. SpringerVerlag. New York, USA.

Sobari, I.; Sumadi; S. Rosniawaty \& E. Wardiana (2020). Perubahan biokimia dan indicator vigor benih kakao pada lima taraf lamanya penyimpanan. Jurnal Tanaman Industri dan Penyegar, 7(3), 163-178.

Soedarsono (1985). Pengangkutan benih coklat dalam bentuk biji tanpa kulit. Warta Balai Penelitian Perkebunan Jember, 1, 14-18.

Sudrajat, D.J.; Nurhasybi \& Y. Bramasto (2017). Standar Pengujian dan Mutu Benih Tanaman Hutan. IPB Press. Bogor, Indonesia.

Sun, L.; S. Liu; Z. Fan; Y. Li; J. Wang; Y. Zhong; Q. Zhang \& X. Duan (2018). The impact of storage temperature on fruit quality and chilling injury of 'Okubao' peaches. International Journal of Food and Bioscience, 1(1), 12-18.

Umarani, R.; E.K. Aadhavan \& M.M. Faisal (2015). Understanding poor storage potential of recalcitrant seeds. Current Science, 108(11), 2023-2035.

Wibowo, A.; D. Nugroho \& U. Sumirat (2020). Seed germination performance of nine Arabica coffee (Coffea arabica L.) varieties under the laboratory condition after six months of storage period. Pelita Perkebunan, 36(3), 203-211. 